\title{
Pliocene Ice Sheet Modelling Intercomparison Project (PLISMIP) - experimental design
}

\author{
A. M. Dolan ${ }^{1, *}$, S. J. Koenig ${ }^{2, *}$, D. J. Hill ${ }^{1,3}$, A. M. Haywood ${ }^{1}$, and R. M. DeConto ${ }^{2}$ \\ ${ }^{1}$ School of Earth and Environment, University of Leeds, Leeds, LS2 9JT, UK \\ ${ }^{2}$ Department of Geosciences, University of Massachusetts, Amherst, MA 01003, USA \\ ${ }^{3}$ British Geological Survey, Keyworth, Nottingham, NG12 5GG, UK \\ *These authors contributed equally to this work.
}

Correspondence to: A. M. Dolan (eeamd@leeds.ac.uk), S. J. Koenig (koenig@geo.umass.edu)

Received: 23 September 2011 - Published in Geosci. Model Dev. Discuss.: 14 October 2011

Revised: 12 June 2012 - Accepted: 22 June 2012 - Published: 18 July 2012

\begin{abstract}
During the mid-Pliocene warm period (3.264 to 3.025 million years ago), global mean temperature was similar to that predicted for the next century and atmospheric carbon dioxide concentrations were slightly higher than today. Sea level was also higher than today, implying a reduction in the extent of the ice sheets. Thus, the mid-Pliocene warm period ( $\mathrm{mPWP}$ ) provides a unique testing ground to investigate the stability of the Earth's ice sheets and their contribution to sea level in a warmer-than-modern world. Climate models and ice sheet models can be used to enhance our understanding of ice sheet stability; however, uncertainties associated with different ice-sheet modelling frameworks mean that a rigorous comparison of numerical ice sheet model simulations for the Pliocene is essential. As an extension to the Pliocene Model Intercomparison Project (PlioMIP; Haywood et al., 2010, 2011a), the Pliocene Ice Sheet Modelling Intercomparison Project (PLISMIP) will provide the first assessment as to the ice sheet model dependency of ice sheet predictions for the MPWP. Here we outline the PLISMIP experimental design and initialisation conditions that have been adopted to simulate the Greenland and Antarctic ice sheets under present-day and warm mid-Pliocene conditions. Not only will this project provide a new benchmark in the simulation of ice sheets in a past warm period, but the analysis of model sensitivity to various uncertainties could directly inform future predictions of ice sheet and sea level change.
\end{abstract}

\section{Rationale}

The response of the Greenland and Antarctic ice sheets to a warming climate is a critical uncertainty in future predictions of climate and sea level (Lemke et al., 2007; Meehl et al., 2007). The climatic feedbacks associated with changes in the cryosphere are generally not included in climate simulations to $2100 \mathrm{AD}$. On this timescale, the losses in Greenland and Antarctic ice sheets are likely to be small (Huybrechts et al., 2002, 2004; van den Broeke, 2009), but changes will certainly have an impact on long-term climate change and scenarios for climate stabilisation (Irvine et al., 2009; Rignot et al., 2011). Current ice sheet models suggest that significant future ice sheet retreat in Greenland and West Antarctica will occur on centennial timescales (Huybrechts and de Wolde, 1999; Greve et al., 2011). However, current models fail to capture the rapid changes that are being observed in the ice sheet today, suggesting more rapid retreat could be possible. Therefore, it is increasingly important to understand the nature and behaviour of the Earth's major ice sheets during warm intervals in Earth history.

The General Circulation Models (GCM) and ice sheet models (ISM) used for simulating future climate change can be applied to retrodict past climatic and ice sheet changes. Unlike future predictions, palaeoclimate and ice sheet simulations can be evaluated against proxy records providing an important test of the model's ability to simulate climates and ice sheets under conditions of enhanced greenhouse gases.

One epoch of geological time receiving considerable attention is the Pliocene (Haywood et al., 2011b). A number 
of studies have taken a modelling approach to investigate Pliocene ice sheets (see Sect. 1.1). However, each of these studies involves a single GCM and ISM, and has employed different modelling techniques, strategies and parameterisations. This means that the model dependency of the results remains unquantified. In response to this, the Pliocene Ice Sheet Modelling Intercomparison Project (PLISMIP) was initiated to compare the performance of a range of existing numerical ice sheet models of varying complexity when simulating ice sheets of the Pliocene.

\subsection{The mid-Pliocene warm period}

As the most recent period in Earth history with global temperatures and levels of atmospheric carbon dioxide $\left(\mathrm{CO}_{2}\right)$ greater than today, the mid-Pliocene warm period (mPWP) provides an important target for palaeoclimate and ice sheet modelling. Mid-Pliocene palaeogeography is close to modern, making it suitable for testing Earth system sensitivity (Lunt et al., 2010) and providing an excellent natural laboratory to test climate and ice sheet dynamics in a warmer world. The mPWP is defined by the United States Geological Survey's PRISM Group (Pliocene Research Interpretation and Synoptic Mapping $\left.{ }^{1}\right)$ as the interval between isotope stages M2/M1 (3.264 Ma) and G21/G20 (3.025 Ma), according to the geomagnetic polarity timescale of Gradstein et al. (2004). The mPWP "time slab" is a climatically distinct period, easily identifiable in marine core records, when the Earth experienced global mean temperatures higher than today. It represents one of the most accessible palaeoclimates to compare with model estimates of late 21st century climate (Haywood et al., 2011b). Additionally, due to the efforts of the PRISM Group, the mPWP is particularly well documented in terms of palaeoenvironmental conditions. Global data sets of multiproxy sea surface temperatures, vegetation cover, topography, and ice volume are readily available as boundary conditions for global climate models (see Dowsett et al., 2010 and references therein).

The most recent climate model predictions suggest that, during Pliocene interglacials, global annual mean temperatures were 2 to $3{ }^{\circ} \mathrm{C}$ higher than the Pre-industrial Era (e.g. Haywood et al., 2009; Lunt et al., 2010). Sea levels were higher than today (estimated to be 10 to $30+\mathrm{m}$ ) meaning that global ice volume was reduced (Dowsett et al., 2010 and references therein; Raymo et al., 2011). Proxy evidence suggests that there may have been large fluctuations in ice cover on West Antarctica (Naish et al., 2009a), and during the interglacials the Greenland ice sheet may have been largely free of ice (Funder et al., 2001; Alley et al., 2010). Some ice may also have been lost from around the margins of East Antarctica (Williams et al., 2010). Unfortunately, much of the geological evidence for this time period is limited and disputed or controversial (see Hill et al., 2007).

\footnotetext{
${ }^{1}$ http://geology.er.usgs.gov/eespteam/prism/
}

Given these uncertainties in geological estimates of Pliocene ice sheets, considerable effort has been devoted to accurately simulating the ice sheets with numerical models (e.g. Hill et al., 2007; Lunt et al., 2008a; Hill, 2009; Lunt et al., 2009; Pollard and DeConto, 2009; Hill et al., 2010; Dolan et al., 2011; Koenig et al., 2011). However, the exact location and extent of the ice sheets remain uncertain as the different modelling frameworks adopted have yielded different results. Through the comparison of a range of ice sheet models under the same boundary conditions and climatological forcing, PLISMIP will reconstruct the most likely geometry and volume of ice masses on Greenland and Antarctica (see Sect. 4.3.2). In doing so, PLISMIP will address the issue of ISM dependency. It should however be noted that, as the geological constraints on ice sheets of the mid-Pliocene are relatively weak, this project does not allow for a complete assessment of the structural uncertainty within ice sheet models. Such an endeavour is better suited to simulations of modern conditions, where ice sheet configurations are much better known. Nevertheless, the first stage of PLISMIP will offer initial insights into the importance of the differences between model predictions of ice sheets of the mid-Pliocene.

\subsection{PLISMIP within PlioMIP and PMIP}

The Palaeoclimate Modelling Intercomparison Project (PMIP) encourages the systematic study of climate models and their predictions (e.g. Joussaume and Taylor, 1995; Hoar et al., 2004; Zheng et al., 2008). GCMs are widely used to simulate and predict the Earth's past, present and future climates (e.g. Solomon et al., 2007). Although broad agreement exists amongst such models, there are significant differences in the details of their predictions, and their sensitivity to increases in atmospheric $\mathrm{CO}_{2}$. This has necessitated the investigation of model dependencies. Therefore, the modelling community has developed initiatives such as PMIP to accurately reconstruct past climates and test models against proxy records. One of the most recent additions to PMIP is the Pliocene Model Intercomparison Project (hereafter referred to as PlioMIP; Haywood et al., 2010, 2011a), which focuses on comparing climate model simulations of the mPWP.

PlioMIP's two-phase approach includes the application of atmosphere-only and coupled ocean-atmosphere GCMs, and $\mathrm{CO}_{2}$ levels for the PlioMIP experiments were set to 405 ppmv for the PlioMIP experiments (Haywood et al., 2010, 2011a). PlioMIP boundary conditions are based on the PRISM3 global reconstruction (Dowsett et al., 2010), which incorporates the following:

- a fractional land/sea mask in keeping with an increase of $25 \mathrm{~m}$ of sea level relative to modern conditions, which is consistent with palaeoshoreline and marine sedimentary evidence (Dowsett and Cronin, 1990; Wardlaw and Quinn, 1991; Krantz, 1991; Lisiecki and Raymo, 2005; Dwyer and Chandler, 2009; Naish and Wilson, 2009); 
- a basic topographic reconstruction based on the Pliocene palaeogeography of Markwick (2007) where the main area of change from modern conditions is in the ice sheet regions (Sohl et al., 2009);

- reconstructions of ice sheet height and extent produced with the high-resolution British Antarctic Survey Ice Sheet Model, utilising the Hadley Centre GCM climatologies produced with PRISM2 boundary conditions (Hill et al., 2007; Hill, 2009);

- a sea-surface temperature (SST) field, reconstructed using a warm-peak averaging technique incorporating multiple temperature proxies from multivariate analysis of fossil planktonic Foraminifers, ostracods and diatoms as well as $\mathrm{Mg} / \mathrm{Ca}$ and alkenone unsaturation index palaeothermometry (Dowsett, 2007; Robinson et al., 2008; Dowsett and Robinson, 2009; Dowsett et al., 2009a, b; Robinson, 2009; summarised in Dowsett et al., 2010);

- a sea ice reconstruction showing ice-free summers in both hemispheres with a mid-Pliocene maximum winter margin at the modern summer sea ice extent. This reconstruction is consistent with the distribution of key diatom taxa (in the Southern Hemisphere; Barron, 1996) and sedimentological data suggesting that Pliocene high latitude winter SSTs resemble modern summer conditions (Dowsett et al., 1994, 2009a; Robinson, 2009);

- reconstructed vegetation based on a combination of internally consistent palaeobotanical data from 202 sites and the predictions of a coupled climate-vegetation model (Salzmann et al., 2008).

Eventually PLISMIP will use all of the data resulting from the PlioMIP experiments to help quantify the uncertainties introduced into $\mathrm{mPWP}$ ice sheet simulations by using a single GCM. However, initially it is necessary to have a first order understanding of how important ice sheet model dependency is in reconstructions of the mid-Pliocene ice sheets. The experimental design for the first stage of PLISMIP, which focuses solely on ice sheet model dependency, is detailed below. This description of the project design and the rationale behind the data sets used will prove valuable during the intercomparison phase of PLISMIP. Results from this project will also provide an invaluable contribution to our understanding of the mid-Pliocene Earth system in general.

\section{Experimental design}

The PLISMIP experimental design is divided into three domains based on the predictive capabilities of the two types of ice sheet models. We use models that only apply the shallowice approximation (SIA) on land or a combination of the SIA and shallow-shelf approximation (SSA) to include floating ice flow (Pollard, 2010; see Sect. 3 for further details). ISMs that use a SIA to represent ice flow will be applied to simulate (i) the East Antarctic Ice Sheet (EAIS) and (ii) the Greenland Ice Sheet (GrIS), while models which use a SSA to represent ice dynamics (see Bueler and Brown, 2009), and therefore have the capability to model the floating marine section of West Antarctica, will be used to model (iii) the whole of Antarctica. Where possible, the SSA models will also be applied to the Greenland ice sheet for comparison with the simulations using SIA ISMs. A summary of the experimental design is shown in Table 1. For each of the three ice sheet domains, five experiments are to be undertaken (Sect. 2.1).

\subsection{Experiments}

\subsubsection{Control simulations}

Control simulations are initiated to understand how well ISMs of differing complexity are able to simulate preindustrial and modern-day ice sheets, in order to highlight any potential biases in the palaeo-simulations. They also ensure that any parameters or initialisation conditions prescribed within the experimental design of PLISMIP do not serve to significantly degrade any ISMs reconstruction of the modern ice sheets.

First, all ISMs are forced with a modern-day climate based on the NCEP reanalysis data set (Kanamitsu et al., 2002), which is partially based on observations (see Sect. 4.1). This allows for comparison of the equilibrated ice sheet response to a present-day climate forcing with independent data on ice sheet geometry (e.g. Bamber et al., 2001), thus highlighting ISM-specific deviations.

Secondly, the pre-industrial control output from the Hadley Centre's Atmosphere-only GCM (HadAM3) is used to force the ISMs (see Sect. 4.1). The reasoning behind this is that any large differences incurred in the equilibrium ice sheet response as a result of using the HadAM3 modelled climatology (rather than observations) may point to potential weaknesses in the Pliocene ice sheet reconstructions with Pliocene HadAM3 climatologies. However, if HadAM3-forced ISMs predict a good modern ice sheet, then this gives confidence in the use of the same modelling framework to predict Pliocene ice sheets.

\subsubsection{Mid-Pliocene warm period simulations (Phase 1)}

Phase 1 ISM simulations use the climatological forcing from the HadAM3 PlioMIP Experiment 1 results (see Sect. 4.1). Phase 1 simulations, as outlined in Table 1, test the sensitivity of the ISMs to initial ice sheet configurations within the ice sheet model, which has an important influence on ice sheet hysteresis (Pollard and DeConto, 2005).

As the ice sheet configurations for the Pliocene are largely unknown, it is difficult to decide with confidence how to initiate the ISMs. Modern ice geometry is almost certainly 
Table 1. Experimental design. Models are run over the three domains of Greenland, East Antarctica, and the whole of Antarctica (including the West Antarctic Ice Sheet). The control phase corresponds to simulations of present-day/pre-industrial conditions and Phases 1 and 2 apply to Pliocene climates. Phase 1 comprises experiments where the initial conditions in the ISMs are altered, whereas Phase 2 experiments focus on changing the boundary condition prescribed in the climate model. Forcing fields for the ISMs are derived from modelled (HadAM3) and reanalysis data sets (NCEP2). Initial conditions refer to the ice sheet configurations and the topographic state used to initiate the ice sheet modelling experiments.

\begin{tabular}{|c|c|c|c|c|c|}
\hline \multirow{2}{*}{ ISM TYPE } & \multirow{2}{*}{ PHASE } & \multirow{2}{*}{ GCM INPUT } & \multicolumn{2}{|c|}{ INITIAL CONDITIONS (ISM) } & \multirow{2}{*}{ RUN ID } \\
\hline & & & Ice Sheet & Topography & \\
\hline \multirow{5}{*}{$\begin{array}{l}\text { Greenland Ice } \\
\text { Sheet Models }\end{array}$} & Control & Modern-day HadAM3 & Modern-day GrIS & Modern & 1 \\
\hline & Control & Reanalysis NCEP & Modern-day GrIS & Modern & 2 \\
\hline & Phase 1 & Pliocene HadAM3, PRISM3 BC & No Ice & $\begin{array}{l}\text { Modern } \\
\text { (isostatically } \\
\text { rebounded) }\end{array}$ & 3 \\
\hline & Phase 1 & Pliocene HadAM3, PRISM3 BC & Prescribed PRISM3 GrIS & $\begin{array}{l}\text { PRISM3 } \\
\text { bedrock }\end{array}$ & 4 \\
\hline & Phase 2 & $\begin{array}{l}\text { Pliocene HadAM3, PRISM3 BC } \\
\text { except no Greenland ice }\end{array}$ & No Ice & $\begin{array}{l}\text { Modern } \\
\text { (isostatically } \\
\text { rebounded) }\end{array}$ & 5 \\
\hline \multirow{5}{*}{$\begin{array}{l}\text { East Antarctic Ice } \\
\text { Sheet Models }\end{array}$} & Control & Modern-day HadAM3 & Modern-day EAIS & Modern & 6 \\
\hline & Control & Reanalysis NCEP & Modern-day EAIS & Modern & 7 \\
\hline & Phase 1 & Pliocene HadAM3, PRISM3 BC & Modern-day EAIS & Modern & 8 \\
\hline & Phase 1 & Pliocene HadAM3, PRISM3 BC & Prescribed PRISM3 EAIS & $\begin{array}{l}\text { PRISM3 } \\
\text { bedrock }\end{array}$ & 9 \\
\hline & Phase 2 & $\begin{array}{l}\text { Pliocene HadAM3, PRISM3 BC } \\
\text { except modern EAIS }\end{array}$ & Modern-day EAIS & Modern & 10 \\
\hline \multirow{5}{*}{$\begin{array}{l}\text { Whole of Antarctic } \\
\text { Ice Sheet Models }\end{array}$} & Control & Modern-day HadAM3 & Modern-day Antarctica & Modern & 11 \\
\hline & Control & Reanalysis NCEP & Modern-day Antarctica & Modern & 12 \\
\hline & Phase 1 & Pliocene HadAM3, PRISM3 BC & Modern-day Antarctica & Modern & 13 \\
\hline & Phase 1 & Pliocene HadAM3, PRISM3 BC & Prescribed PRISM3 Antarctica & $\begin{array}{l}\text { PRISM3 } \\
\text { bedrock }\end{array}$ & 14 \\
\hline & Phase 2 & $\begin{array}{l}\text { Pliocene HadAM3, PRISM3 BC } \\
\text { except modern Antarctica }\end{array}$ & Modern-day Antarctica & Modern & 15 \\
\hline
\end{tabular}

too large based on sea level records of higher-than-modern sea level (Dowsett et al., 2010). Ice-free conditions with isostatically rebounded bedrock are a possibility for Greenland (Raymo et al., 2011 and references therein) and West Antarctica (Pollard and DeConto 2009), but not for East Antarctica. The best available approximations for Pliocene ice sheets used as boundary conditions for HadAM3 (PRISM3; Hill, 2009; Haywood et al., 2010) are based on previous modelling studies and may be subject to model-dependent uncertainties. Therefore, we have chosen to initiate the PLISMIP experiments with (i) a maximum envelope of ice sheet geometries, i.e. ice free for Greenland and modern ice for the Antarctic ice sheets, and (ii) an approximation based on the PRISM3 data set (see Table 1). These initial ice sheet configurations are shown in Fig. 3.

\subsubsection{Mid-Pliocene warm period simulations (Phase 2)}

Phase 2 further quantifies uncertainties in the simulation of ice sheets in the mPWP by altering the ice sheet configuration prescribed in the GCM (HadAM3). In the original PlioMIP Pliocene HadAM3 simulation, the prescribed ice sheet was based upon the PRISM3 data set. For the reasons outlined in Sect. 2.1.2, this uncertain ice sheet configuration may lead to an over- or underestimation of the climatic forcing appropriate for the mPWP. Therefore, additional climate model experiments using HadAM3 were performed using PRISM3 boundary conditions, but with ice-free (isostatically rebounded) conditions on Greenland (Fig. 3a) and a modern ice sheet over Antarctica (Fig. 3c). These new climatologies provided by the GCM will be used to force the ISMs for the Phase 2 experiments (see Table 1). 
A

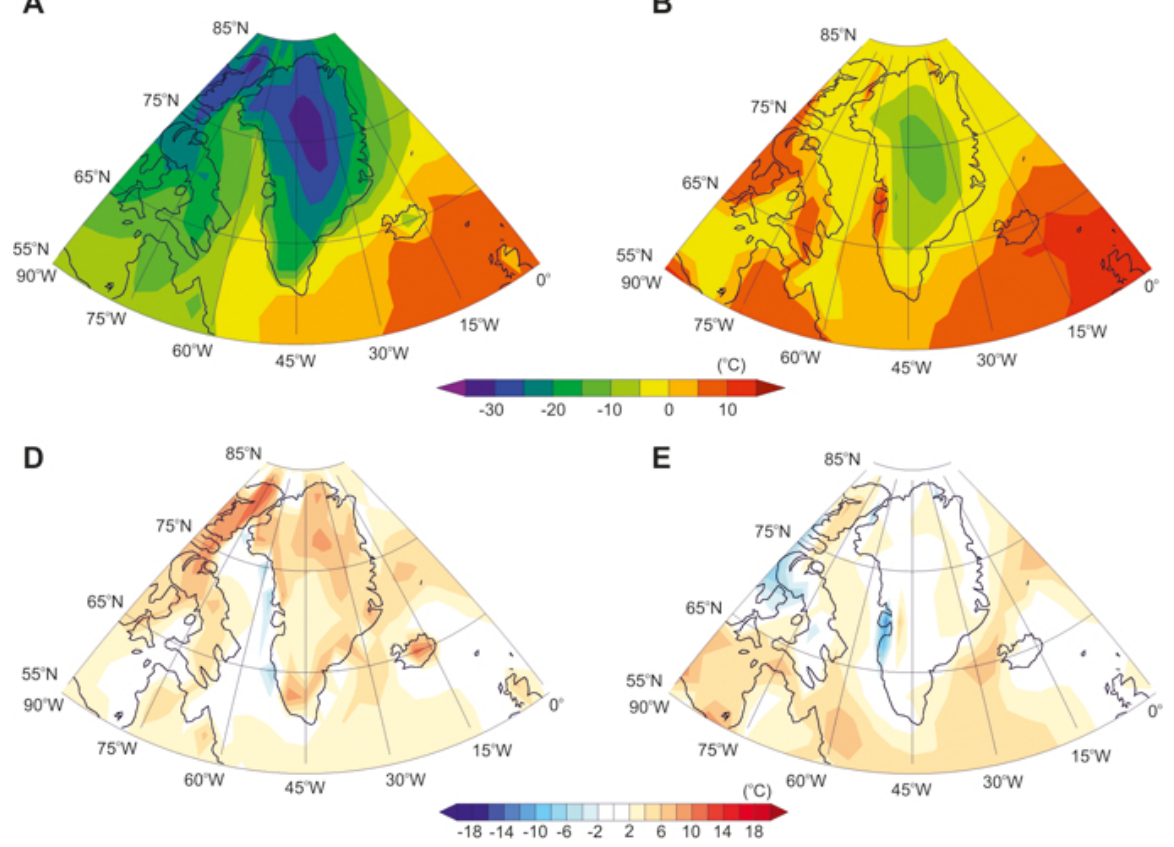

C
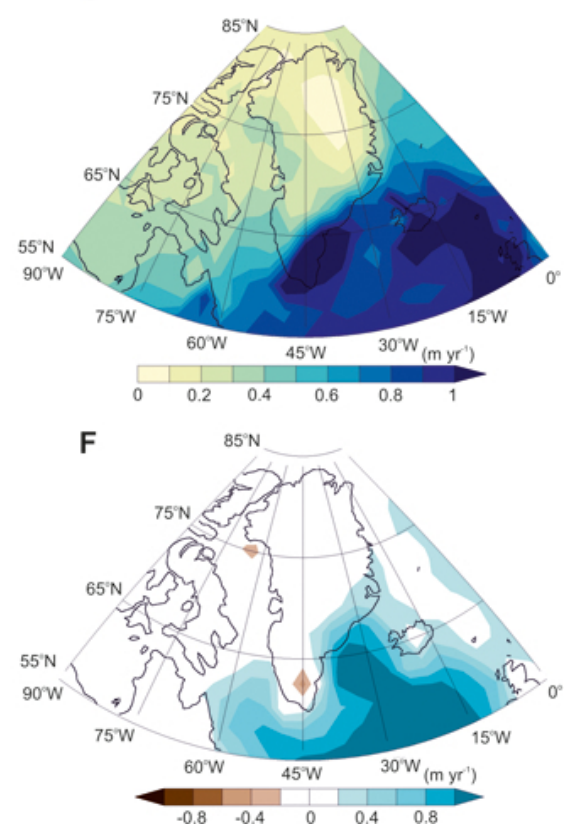

Fig. 1. Control phase driving climatologies. HadAM3 modelled (a) mean annual and (b) summer (July) surface air temperature $\left({ }^{\circ} \mathrm{C}\right)$, (c) mean annual precipitation rate $\left(\mathrm{m} \mathrm{yr}^{-1}\right)$ and the differences between NCEP reanalysis data and HadAM3 (NCEP-HadAM3) for (d) annual mean and (e) summer surface air temperature $\left({ }^{\circ} \mathrm{C}\right)$ and (f) precipitation $\left(\mathrm{m} \mathrm{yr}^{-1}\right)$ over Greenland. Note that NCEP reanalysis data were interpolated to the HadAM3 GCM grid before calculating the differences.

The choice of prescribing a modern Antarctic ice sheet in the GCM may appear inconsistent with prescribing an ice-free Greenland and irreconcilable with the higher-thanmodern Pliocene sea level records (see Dowsett et al., 2010). However, the prevailing paradigm is that there has been little change in Antarctica since the Miocene, especially in East Antarctica. Therefore, the reduction of East Antarctic ice in PRISM3 may be pre-conditioning the ice sheet models to simulate ice sheet retreat, especially as other ice sheet modelling studies have been unable to produce such significant ice retreat out of the Wilkes and Aurora Subglacial Basins (e.g. Pollard and DeConto, 2009).

\section{Ice sheet models}

As noted above, there are two types of ISM taking part in PLISMIP: shallow ice approximation and shallow shelf approximation ISMs (for an overview, see Pollard, 2010). The shallow ice approximation (hereafter SIA, Hutter, 1983) to the Stokes equations is a widely adopted, computationally efficient approach to modelling ice sheet flow. The SIA method is valid for ice sheets that have a small aspect ratio and where the bedrock and surface slopes are sufficiently small that the normal components of stress can be neglected (e.g. Bueler and Brown, 2009). SIA considers only horizontal shear stresses, which are concentrated towards the base of the ice sheet and gravity is assumed to be the driver of ice flow. Although the SIA approach prohibits any representation of higher-order stresses in the ice, it has been shown to perform well compared with full stress models (Leysinger Vieli and Gudmundsson, 2004). SIA ISMs are used in the experiments simulating the Greenland and East Antarctic ice sheets in this project.

Shallow-shelf approximation (SSA) models use a different balance of momentum equations to determine the ice flow. Typically, SSA models describe a membrane-type flow with the ice floating or sliding over a weak base. Although SSA models are best applied to ice shelves as there are no shear stresses acting on the base of the floating ice, they can be used on grounded ice if they include additional basal resistance terms or they can be combined with SIA models to provide a single SIA/SSA hybrid model (e.g. Bueler and Brown, 2009; Pollard and DeConto, 2007), which is capable of simulating the complete grounded/floating ice sheet/shelf system. In the case of Antarctica, where the buttressing effects of ice shelves are particularly important for the simulation of the West Antarctic Ice Sheet, (WAIS), SSA and SIA/SSA ISMs are used. Nevertheless, it should be noted that many of the marine-ice sheet/shelf interface processes depend strongly on local-scale sea surface temperatures (Pritchard et al., 2012). The resolution of the climate models used in this study may not be high enough to fully capture realistic local-scale variability. Techniques used to overcome these problems of climate-ice sheet model coupling will be documented fully 
A
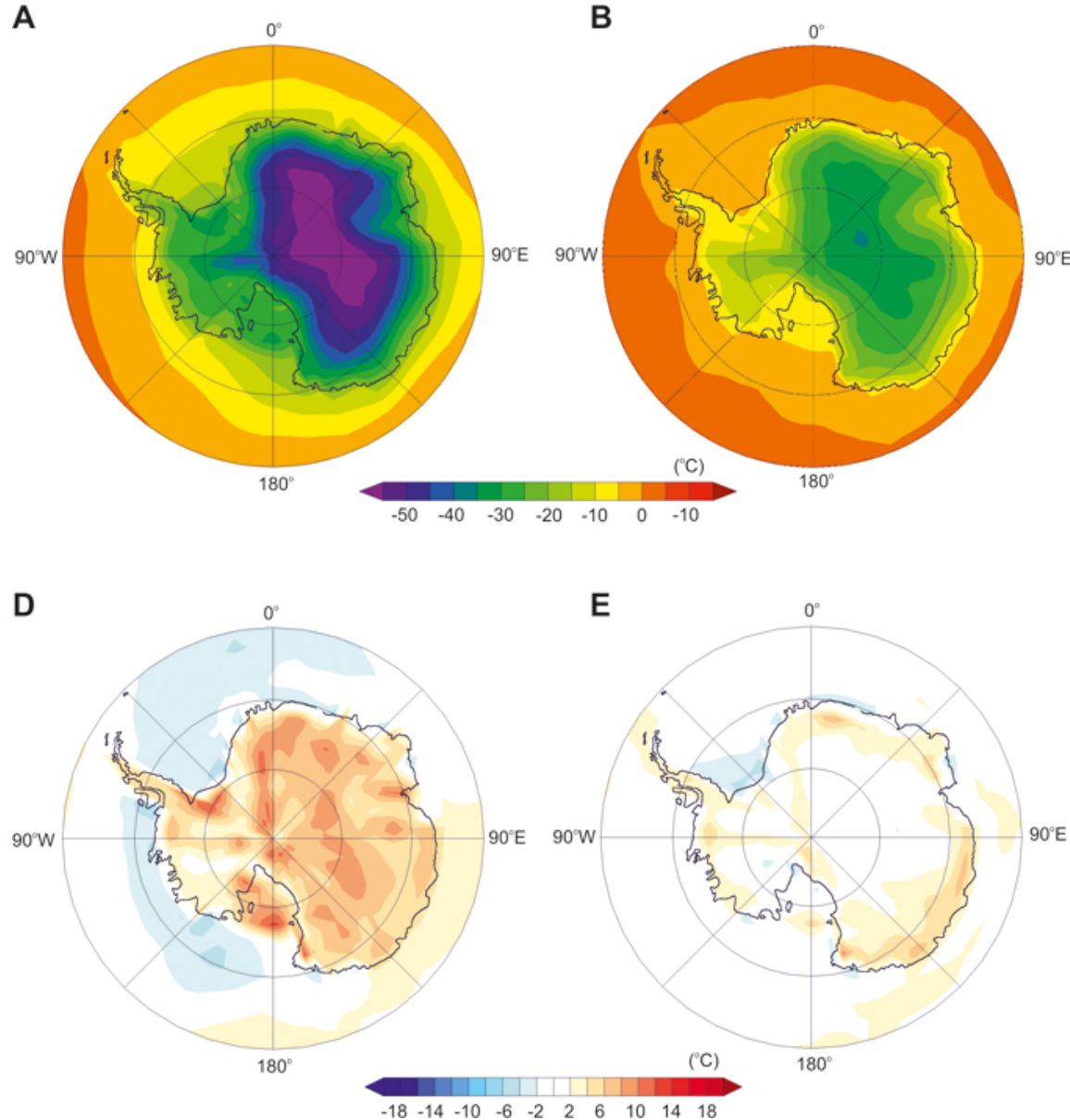

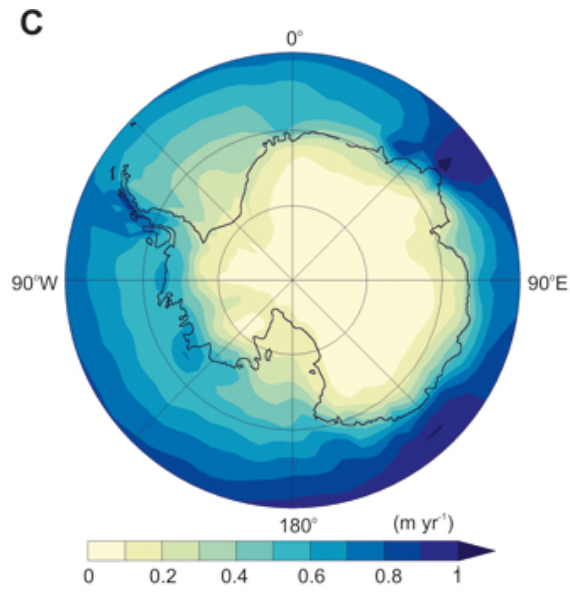

$\mathbf{F}$

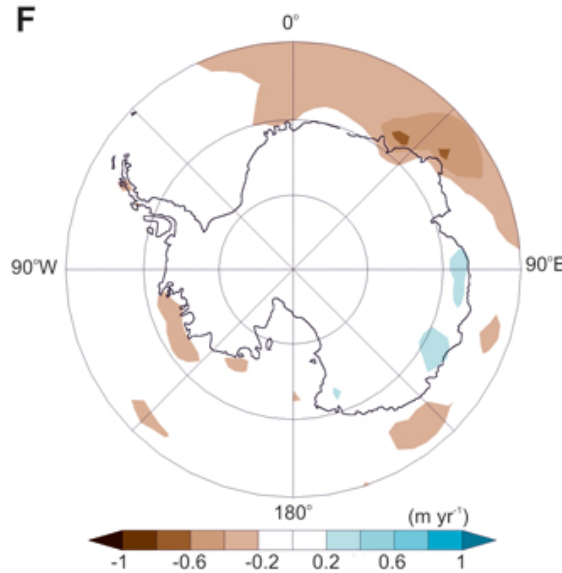

Fig. 2. Control phase driving climatologies. HadAM3 modelled (a) mean annual and (b) summer (January) surface air temperature $\left({ }^{\circ} \mathrm{C}\right)$, (c) mean annual precipitation rate $\left(\mathrm{m} \mathrm{yr}^{-1}\right)$ and the differences between NCEP reanalysis data and HadAM3 (NCEP-HadAM3) for (d) annual mean and (e) summer surface air temperature $\left({ }^{\circ} \mathrm{C}\right)$ and (f) precipitation $\left(\mathrm{m} \mathrm{yr}^{-1}\right)$ over Antarctica. Note that NCEP reanalysis data were interpolated to the HadAM3 GCM grid before calculating the differences.

by participating groups and in the resulting papers that will stem from this project.

\section{Ice sheet model simulations, set-up and output}

\subsection{Input climatologies}

The NCEP/DOE AMIP-II Reanalysis (NCEP/DOE-2, Kanamitsu et al., 2002), a data assimilation product based on the widely used NCEP/NCAR Reanalysis (NCEP-1), is used as the driving climatology set for the control phase. It features improvements on NCEP-1 by fixing known errors and by updating parameterizations of physical processes, including a smoother orography, and a non-local boundary layer parameterization, as well as a new deep convection parameterization. The reanalysis was updated in 2005 and 2008, fixing errors associated with sea ice and the source code. Both NCEP/NCAR-1 and NCEP/DOE-2 have been used to validate climate model results, and importantly for this project, the data are in agreement with other reanalysis products over high latitudes (e.g. Serreze and Hurst, 2000; Kharin et al., 2007). The data are available globally, with a spectral horizontal resolution of T62 and 28 vertical levels. Climate parameters are available up to four times daily from 1979 to the present day.

The GCM climatologies used in this project are provided by the HadAM3 GCM, which has a horizontal resolution of $2.5^{\circ}$ in latitude, $3.75^{\circ}$ in longitude, and 19 vertical layers in the atmosphere (see Pope et al., 2000 for further details). HadAM3 is the preferred model for PLISMIP, because there is a long history of Pliocene climate simulations using this model (e.g. Haywood and Valdes, 2006; Haywood et al., 2000, 2002, 2009; Hill, 2009; Hill et al., 2007, 2010), and the model is already equipped to run with altered PRISM boundary conditions (as described above in Sect. 1.2).

Figures 1 and 2 show how the NCEP reanalysis climate differs from the HadAM3 pre-industrial climate over Greenland and Antarctica. HadAM3 is slightly cooler over 


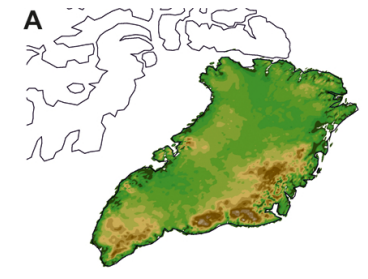

C
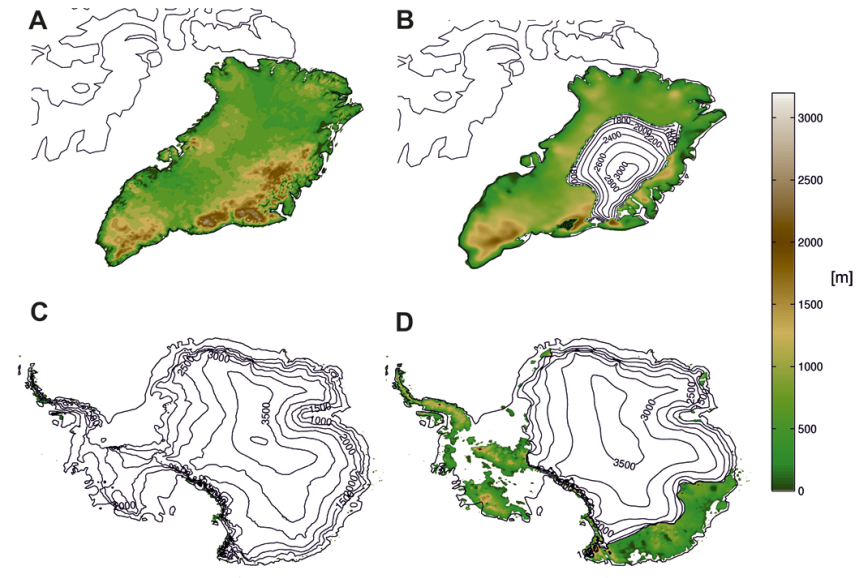

Fig. 3. Ice sheet model initial conditions showing (a) an ice-free Greenland, (b) PRISM3 ice over Greenland (Hill, 2009; Dowsett et al., 2010), (c) the modern Antarctic ice sheet topography (m) and (d) PRISM3 Antarctic ice.

Greenland $\left(2\right.$ to $\left.6{ }^{\circ} \mathrm{C}\right)$, and up to $10^{\circ} \mathrm{C}$ cooler over Antarctica. Precipitation rates between the two climatologies are similar over the ice sheet areas. These deviations will be taken into consideration in the analysis of ice sheet model results of modern and Pliocene climates.

The difference between HadAM3 modelled pre-industrial and Pliocene climates can be seen in Figs. 4 and 5. Over Greenland and Antarctica, there are mean annual temperature increases in the Pliocene of over $20^{\circ} \mathrm{C}$ compared with preindustrial temperatures over those areas where prescribed Pliocene ice sheet configurations (PRISM3) differ significantly from modern-day extents (Fig. 3). In general, the ice sheet regions are also wetter during the mPWP with precipitation increases as high as $0.8 \mathrm{~m} \mathrm{yr}^{-1}$, although the southern tip of Greenland receives markedly less precipitation (a reduction of around $0.5 \mathrm{~m} \mathrm{yr}^{-1}$ ) as observed in other Pliocene studies applying HadAM3 runs (e.g. Hill et al., 2010).

\subsection{ISM set-up}

The ISMs are forced with average annual and monthly temperature and precipitation data sets calculated from climatological means of the NCEP data set and HadAM3 simulations. NCEP data are provided at a grid resolution of $2 \times 2^{\circ}$. HadAM3 driving fields as well as the PRISM3 landsea mask and global topography are supplied at the resolution of HadAM3, i.e. on a $73 \times 96$ global grid.

Standard bedrock topographies for running the ISMs originate from EISMINT (Huybrechts et al., 1996) for the Greenland Ice Sheet and from BEDMAP for the Antarctic ice sheets (Lythe and Vaughan, 2001). These data, along with the PRISM3 ice sheet configurations (Fig. 3), are supplied on a $20 \times 20 \mathrm{~km}$ grid, which is the preferred ice sheet model resolution for the PLISMIP simulations. All data required to
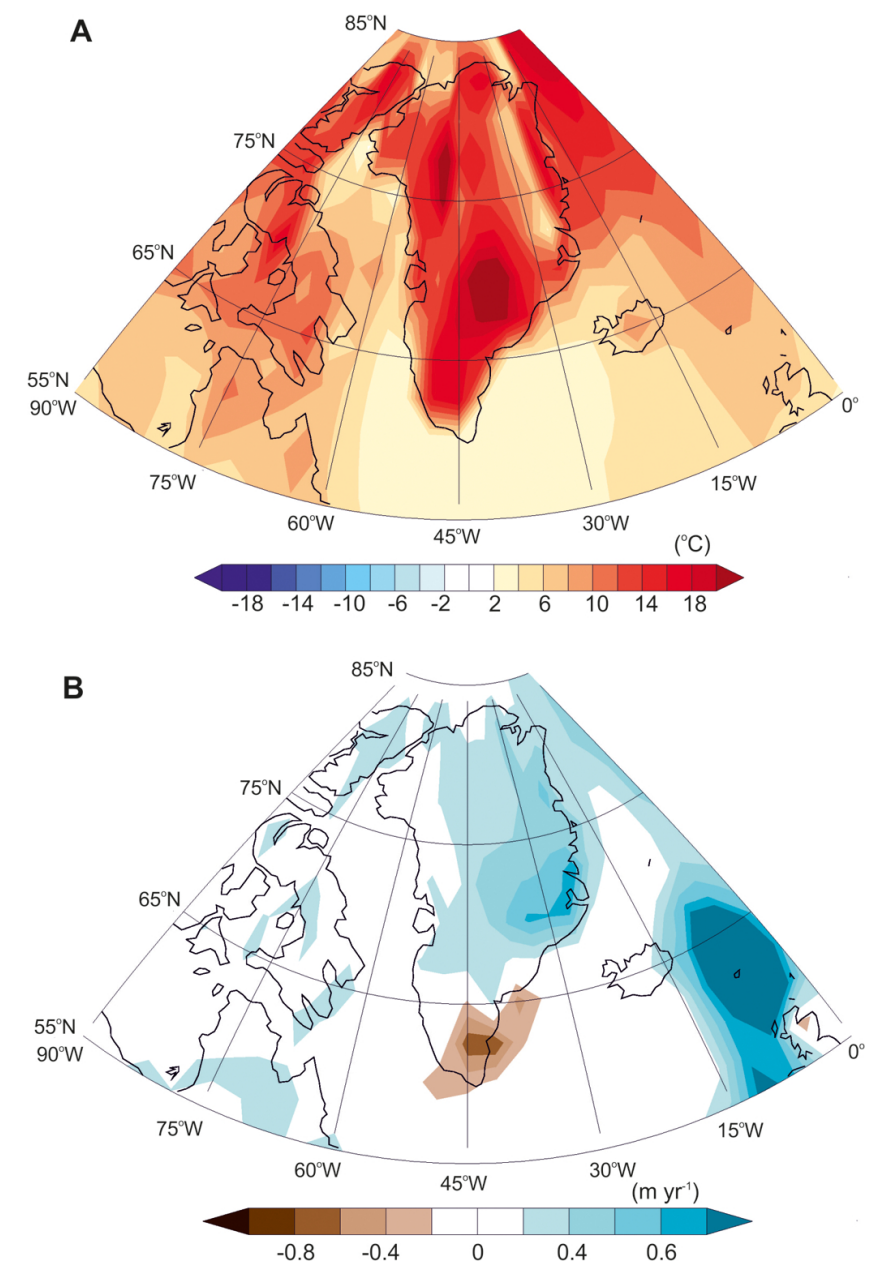

Fig. 4. (a) HadAM 3 Pliocene minus pre-industrial mean annual surface air temperature $\left({ }^{\circ} \mathrm{C}\right)$ and (b) mean annual precipitation rate $\left(\mathrm{m} \mathrm{yr}^{-1}\right)$ anomaly over Greenland. Pliocene simulations include the PRISM3 ice sheet boundary conditions (Fig. 3b; Hill, 2009; Dowsett et al., 2010).

run the ISM simulations are available on the PLISMIP website, which is hosted at the University of Leeds. ${ }^{2}$

Unlike many previous ISM intercomparison projects (e.g. EISMINT: Huybrechts et al., 1996 and ISMIP-HOM: Pattyn et al., 2008), the different ISMs are set up in standard mode. This means that the optimal set-up or standard ISM configuration that gives each ice sheet modelling group the best simulation of the present-day ice sheets should be used. Modelling groups will therefore be able to decide if they perform the mid-Pliocene simulations with the ISM in absolute mode or if the climate forcing will be applied to the present-day climate as a perturbation (anomaly mode). Such a methodology was chosen in order to include the uncertainties introduced into ISM predictions by the choice of ISM set-up, and because the geological constraints on mid-Pliocene ice

\footnotetext{
${ }^{2}$ https://www.see.leeds.ac.uk/redmine/public/projects/plismip please contact A. M. Dolan for access to this website
} 

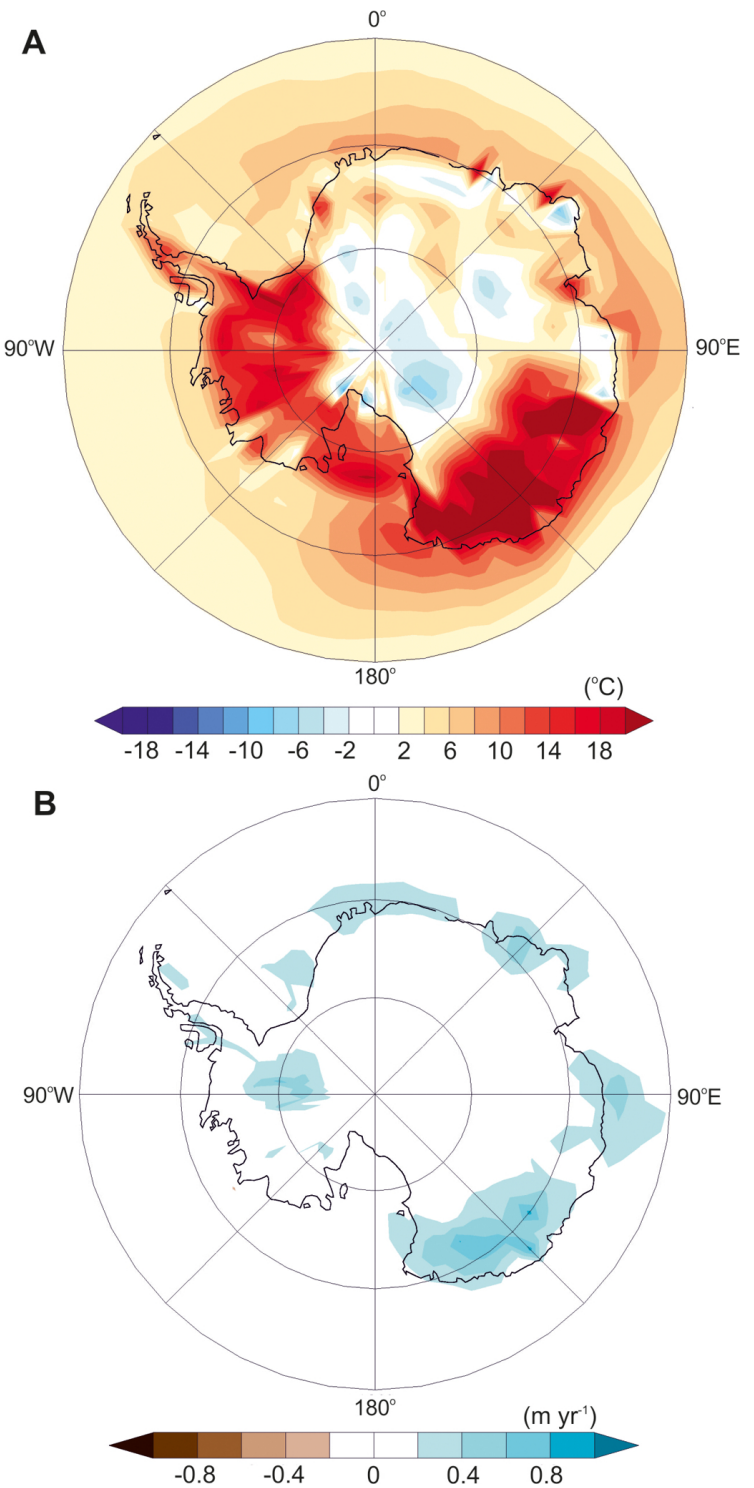

Fig. 5. (a) HadAM 3 Pliocene minus pre-industrial mean annual surface air temperature $\left({ }^{\circ} \mathrm{C}\right)$ and (b) mean annual precipitation rate $\left(\mathrm{m} \mathrm{yr}^{-1}\right)$ anomaly over Antarctica. Pliocene simulations include the PRISM3 ice sheet boundary conditions (Fig. 3d; Hill, 2009; Dowsett et al., 2010).

sheets are insufficient to provide a full assessment of ISM structural uncertainty. Therefore, the computation of, for example, surface mass balance or basal melting, the treatment of the grounding line and iceberg calving will all be left as standard in each ISM. Such flexibility will allow for maximum participation from modelling groups, and the results will reflect the true variation within the ice sheet modelling frameworks.

All ice sheet simulations are to be initialised with the conditions stated in Table 1. If the ISM is required to start from no ice on isostatically rebounded bedrock, participants are asked to use their own bedrock and rebound model. Where the initial ice sheet is less than modern, the ice sheet configuration along with a rebounded topography in areas where ice is not present will be provided.

Although the ice sheet models will remain in their standard configuration, certain intrinsic parameterisations that are known to have a significant effect on predicted ice sheets given the same climate forcing should be prescribed. The atmospheric lapse rate and positive degree-day factors (used in the calculation of surface mass balance; e.g. Reeh, 1991) have been shown to have the most dominant effect on ice surface extent (Stone et al., 2010). Lapse rate corrections are to be applied to account for the difference between the surface height in the GCM and the ISM. Corrections are made for temperature fields following the method outlined in Thompson and Pollard (1997). Initially, the climate model topography and surface air temperatures are horizontally interpolated to the ISM grid and then the climate model temperature is corrected by

$T-\gamma *\left(Z_{\mathrm{ISM}}-Z_{\mathrm{GCM}}\right)$

where $T$ is surface air temperature, $Z_{\text {ISM }}$ elevation of the ISM and $Z_{\mathrm{GCM}}$ is the climate model elevation, and $\gamma$ is the uniform lapse rate correction set to $8{ }^{\circ} \mathrm{C} \mathrm{km}^{-1}$. Currently, there is no similar simple relationship between precipitation and altitude. Where downscaling methods do exist (e.g. Ritz et al., 2007), the ratio of precipitation change with temperature change is poorly constrained (Charbit et al., 2002). Therefore, no correction for precipitation is specified within the experimental design. If, however, modelling groups already prescribe a precipitation correction as standard within their ISM, this will be documented during the analysis of results.

Positive degree-day (PDD) factors for ice and snow will be set to $8 \mathrm{~mm} \mathrm{~d}^{-1}{ }^{\circ} \mathrm{C}^{-1}$ and $3 \mathrm{~mm} \mathrm{~d}^{-1}{ }^{\circ} \mathrm{C}^{-1}$, respectively. These values are within the range of modern observations (Braithwaite, 1995; Hock, 2003) and the standard values used in many Pliocene ice sheet modelling studies (e.g. Hill et al., 2007; Lunt et al., 2008b; Hill et al., 2010; Koenig et al., 2011). Differences in the mass balance schemes of the ice sheet models used will be documented thoroughly in subsequent analyses (see Sect. 4.3.2).

The run length is specified as $30 \mathrm{kyr}$ for Greenland and 100 kyr for Antarctica. If a change in total volume of less than $0.01 \%$ is not reached by the final $10000 \mathrm{yr}$ for Antarctica and the final $1000 \mathrm{yr}$ for Greenland, the ISMs are to be extended in steps of 10000 and $50000 \mathrm{yr}$ for Greenland and Antarctica respectively, until the ice sheet has reached equilibrium.

\subsection{Output}

\subsubsection{Model requirements}

Spatial and temporal output of a number of fields will be required from each ISM (see Table S1; Supplement). The temporal fields will be used to assess whether the ice sheet has 
reached equilibrium or is in a state of oscillation. All ISM results will contain time series of grounded ice volume $\left(\mathrm{m}^{3}\right)$ and area $\left(\mathrm{m}^{2}\right)$ in steps of $100 \mathrm{yr}$ for Greenland and $1000 \mathrm{yr}$ for Antarctica. However, the main focus of the analysis of the project will be on the equilibrium ice sheets submitted for each simulation. For this, we request the submission of surface mass balance ( $\mathrm{m} \mathrm{yr}^{-1}$ of water equivalent), velocity $\left(\mathrm{m} \mathrm{yr}^{-1}\right)$, bed elevation $(\mathrm{m})$, and surface elevation $(\mathrm{m})$ fields on the same spatial domains as the gridded input boundary conditions.

\subsubsection{Planned analyses}

Results from the initial stage of PLISMIP will enable the dependency of mid-Pliocene ice sheet reconstructions on the ISM used to be quantified for the first time. Each of the resulting papers will begin with a detailed description of the participating ice sheet models. Any problems with implementation or the choice of parameter values will be presented as this will be critical in assessing the results. ISM specific results from previous MIPs will also be taken into consideration where appropriate.

Differences in the model-predicted ice sheet thicknesses, the areal extent of the ice sheet and ice sheet volume will be evaluated. Where possible, proxy evidence will also be used to evaluate the results. Based on the range of scenarios and simulated ice sheets, and the caveats associated with the intercomparison set-up, it will then be possible to reconstruct the most likely geometry and volume of ice masses on Greenland and Antarctica. Although this will be a useful contribution to our understanding of the mid-Pliocene ice sheets, it should be reiterated that such an approach does not take into account all types of structural uncertainty within the ISM and this will need to be highlighted as a potential limitation of the results.

\section{Conclusions and outlook}

This paper provides an overview of the experimental design for the Pliocene Ice Sheet Modelling Intercomparison Project (PLISMIP), which is being undertaken as part of PlioMIP, the latest addition to the PMIP experiments. The project makes use of state-of-the-art ISMs of various complexities to reconstruct the nature and extent of ice sheets of the midPliocene warm period. PLISMIP has the direct intention of quantifying both the uncertainties in ice sheet reconstructions introduced by using a single ISM, as well as the biases that result from a range of assumptions that are necessary to initiate the modelling experiments. The future evolution of PLISMIP will also take into account climate model dependency of the ice sheet modelling results. This has the potential to outweigh any variation between ice sheet models, but will only be undertaken once the full suite of PlioMIP GCM results have been submitted. In its entirety, this project will not only shed light on the understanding of palaeo ice sheet variability, but also the analysis of the impact of various model uncertainties will help assess the sensitivity of the Greenland and Antarctic ice sheets in a warmer-than-modern world.

\section{Supplementary material related to this article is available online at: http://www.geosci-model-dev.net/5/ 963/2012/gmd-5-963-2012-supplement.pdf.}

Acknowledgements. This work is a product of the Pliocene Model Intercomparison Project (PlioMIP), which is part of the international Palaeoclimate Modelling Intercomparison Project (PMIP). The Natural Environment Research Council (NERC) is acknowledged for its support to AMD. The US National Science Foundation under the award ATM-0513402 is acknowledged for its support to SJK and RMD. DJH acknowledges the Leverhulme Trust for their support through the funding of a Leverhulme Early Career Fellowship (ECF-2011-205), financially co-supported by the British Geological Survey and National Centre for Atmospheric Science. AMH also acknowledges NERC and the Leverhulme Trust for the award of a Philip Leverhulme Prize (2008). We also thank Bas de Boer for his helpful comments on the draft manuscript and Daniel Lunt for providing the HadAM3 climatologies.

Edited by: P. Huybrechts

\section{References}

Alley, R. B., Andrews, J. T., Brigham-Grette, J., Clarke, G. K. C., Cuffey, K. M., Fitzpatrick, J. J., Funder, S., Marshall, S. J., Miller, G. H., Mitrovica, J. X., Muhs, D. R., Otto-Bliesner, B. L., Polyak, L., and White, J. W. C.: History of the Greenland Ice Sheet: paleoclimatic insights, Quaternary Sci. Rev., 29, 17281756, 2010.

Bamber J. L., Ekholm S., and Krabill W. B.: A new, high-resolution digital elevation model of Greenland fully validated with airborne laser altimeter data, J. Geophys. Res., 106, 6733-6745, doi:10.1029/2000JB900365, 2001.

Barron, J. A.: Diatom constraints on sea surface temperatures and sea ice distribution during the middle part of the Pliocene, USGS Open-File Report, 96-713, 1-45, 1996.

Braithwaite, R. J.: Positive degree-day factors for ablation on the Greenland ice sheet studied by energy-balance modelling, J. Glaciol., 41, 153-160, 1995.

Bueler, E. and Brown, J.: Shallow shelf approximation as a sliding law in a thermomechanically coupled ice sheet model, J. Geophys. Res., 114, F03008, doi:10.1029/2008jf001179, 2009.

Charbit, S., Ritz, C., and Ramstein, G.: Simulations of Northern Hemisphere ice-sheet retreat: sensitivity to physical mechanisms involved during the Last Deglaciation, Quaternary Sci. Rev., 21, 243-265, doi:10.1016/s0277-3791(01)00093-2, 2002.

Dolan, A. M., Haywood, A. M., Hill, D. J., Dowsett, H. J., Hunter, S. J., Lunt, D. J., and Pickering, S .J.: Sensitivity of Pliocene ice sheets to orbital forcing, Palaeogeogr. Palaeocl., 309, 98-110, 2011. 
Dowsett, H. J.: The PRISM palaeoclimate reconstruction and Pliocene sea-surface temperature, in: Deep-time perspectives on climate change: marrying the signal from computer models and biological proxies, edited by: Williams, M., Haywood, A. M., Gregory, J., and Schmidt, D. N., Micropalaeont. Soc. Spec. Pub., Geol. Soc. London, 459-480, 2007.

Dowsett, H. J. and Cronin, T. M.: High eustatic sea level during the middle Pliocene: Evidence from the southeastern US Atlantic Coastal Plain, Geology, 18, 435-438, 1990.

Dowsett, H. J. and Robinson, M. M.: Mid-Pliocene equatorial Pacific sea surface temperature reconstruction: a multi-proxy perspective, Philos. T. R. Soc. A, 367, 109-125, 2009.

Dowsett, H. J., Thompson, R., Barron, J., Cronin, T., Fleming, F., Ishman, S., Poore, R., Willard, D. and Holtz Jr., T.: Joint investigations of the Middle Pliocene climate I: PRISM paleoenvironmental reconstructions, Global Planet. Change, 9, 169-195, 1994.

Dowsett, H. J., Chandler, M. A., and Robinson, M. M.: Surface temperatures of the Mid-Pliocene North Atlantic Ocean: implications for future climate, Philos. T. R. Soc. A, 367, 69-84, 2009a.

Dowsett, H. J., Robinson, M. M., and Foley, K. M.: Pliocene threedimensional global ocean temperature reconstruction, Clim. Past, 5, 769-783, doi:10.5194/cp-5-769-2009, 2009b.

Dowsett, H. J., Robinson, M. M., Haywood, A. M., Salzmann, U., Hill, D. J., Sohl, L. E., Chandler, M.,Williams, M., Foley, K., and Stoll, D. K.: The PRISM3D paleoenvironmental reconstruction., Stratigraphy, 7, 123-139, 2010.

Dwyer, G. S. and Chandler, M. A.: Mid-Pliocene sea level and continental ice volume based on coupled benthic $\mathrm{Mg} / \mathrm{Ca}$ palaeotemperatures and oxygen isotopes, Philos. T. R. Soc. A, 367, 157168, 2009.

Funder, S., Bennike, O., Böcher, J., Israelson, C., Petersen, K. S. and Símonarson, L. A.: Late Pliocene Greenland - The Kap København Formation in North Greenland, Bull. Geol. Soc. Denmark, 48, 117-134, 2001.

Gradstein, F. M., Ogg, J. O., and Smith, A. G. (Eds.): A geologic time scale, Cambridge, UK, Cambridge University Press, 589 pp., 2004.

Greve, R., Saito, F., and Abe-Ouchi, A.: Initial results of the SeaRISE numerical experiments with the models SICOPOLIS and IcIES for the Greenland ice sheet, Ann. Glaciol., 52, 23-30, 2011.

Haywood, A. M. and Valdes, P. J.: Vegetation cover in a warmer world simulated using a dynamic global vegetation model for the Mid-Pliocene, Palaeogeogr. Palaeocl., 237, 412-427, 2006.

Haywood, A. M., Valdes, P. J., and Sellwood, B. W.: Global scale palaeoclimate reconstruction of the middle Pliocene climate using the UKMO GCM: initial results, Global Planet. Change, 25, 239-256, 2000.

Haywood, A. M., Valdes, P. J., Francis, J. E., and Sellwood, B. W.: Global middle Pliocene biome reconstruction: A data/model synthesis, Geochem. Geophy. Geosy., 3, 1072, doi:10.1029/2002GC000358, 2002.

Haywood, A. M., Chandler, M. A., Valdes, P. J., Salzmann, U., Lunt, D. J., and Dowsett, H. J.: Comparison of mid-Pliocene climate predictions produced by the HadAM3 and GCMAM3 General Circulation Models, Global Planet. Change, 66, 208-224, 2009.

Haywood, A. M., Dowsett, H. J., Otto-Bliesner, B., Chandler, M. A., Dolan, A. M., Hill, D. J., Lunt, D. J., Robinson, M. M., Rosen- bloom, N., Salzmann, U., and Sohl, L. E.: Pliocene Model Intercomparison Project (PlioMIP): experimental design and boundary conditions (Experiment 1), Geosci. Model Dev., 3, 227-242, doi:10.5194/gmd-3-227-2010, 2010.

Haywood, A. M., Dowsett, H. J., Robinson, M. M., Stoll, D. K., Dolan, A. M., Lunt, D. J., Otto-Bliesner, B., and Chandler, M. A.: Pliocene Model Intercomparison Project (PlioMIP): experimental design and boundary conditions (Experiment 2), Geosci. Model Dev., 4, 571-577, doi:10.5194/gmd-4-571-2011, 2011a.

Haywood, A. M., Ridgwell, A., Lunt, D. J., Hill, D. J., Pound, M. J., Dowsett, H. J., Dolan, A. M., Francis, J. E., and Williams, M.: Are there pre-Quaternary geological analogues for a future greenhouse warming?, Philos. T. R. Soc. A, 369, 933-956, 2011b.

Hill, D. J.: Modelling Earth's Cryosphere during peak Pliocene warmth, Ph.D. Thesis, Ph. D. Thesis, Ph. D. Thesis, University of Bristol, 368 pp., 2009.

Hill, D. J., Haywood, A. M., Hindmarsh, R. C. M., and Valdes, P. J.: Characterizing ice sheets during the Pliocene: evidence from data and models, in: Deep-Time Perspectives on Climate Change: Marrying the signal from Computer Models and Biological Proxies, edited by: Williams, M., Haywood, A. M., Gregory, J., and Schmidt, D. N., Micropalaeont. Soc. Spec. Pub., Geol. Soc. London, 517-538, 2007.

Hill, D. J., Dolan, A. M., Haywood, A. M., Hunter, S. J., and Stoll, D. K.: Sensitivity of the Greenland Ice Sheet to Pliocene sea surface temperatures, Stratigraphy, 7, 111-122, 2010.

Hoar, M. R., Palutikof, J. P., and Thorne, M. C.: Model intercomparison for the present day, the mid-Holocene, and the Last Glacial Maximum over western Europe, J. Geophys. Res., 109, D08104, doi:10.1029/2003JD004161, 2004.

Hock, R.: Temperature index melt modelling in mountain areas, J. Hydrol., 282, 104-115, 2003.

Hutter, K.: Theoretical Glaciology: Material Science of Ice and the Mechanics of Glaciers and Ice Sheets, Springer, 548 pp., 1983.

Huybrechts, P. and de Wolde, J.: The Dynamic Response of the Greenland and Antarctic Ice Sheets to Multiple-Century Climatic Warming, J. Climate, 12, 2169-2188, 1999.

Huybrechts, P., Payne, A. J., and the EISMINT Intercomparison Group: The EISMINT benchmarks for testing ice-sheet models, Ann. Glaciol., 23, 1-12, 1996.

Huybrechts, P., Janssens, I., Poncin, C., and Fichefet, T.: The response of the Greenland ice sheet to climate changes in the 21st century by interactive coupling of an AOGCM with a thermomechanical ice-sheet model, Ann. Glaciol., 35, 409-415, 2002.

Huybrechts, P., Gregory, J., Janssens, I., and Wild, M: Modelling Antarctic and Greenland volume changes during the 20th and 21 st centuries forced by GCM time slice integrations, Global Planet. Change, 42, 83-105, 2004.

Irvine, P. J., Lunt, D. J., Stone, E. J., and Ridgwell, A.: The fate of the Greenland Ice Sheet in a geoengineered, high $\mathrm{CO}_{2}$ world, Environ. Res. Lett., 4, 045109, doi:10.1088/1748-9326/4/4/045109, 2009.

Joussaume, S. and Taylor, K. E.: Proceedings of the first internal AMIP scientific conference, WCRP Report, 425-430, 1995.

Kanamitsu, M., Ebisuzaki, W., Woollen, J., Yang, S. K., Hnilo, J. J., Fiorino, M., and Potter, G. L.: NCEP-DOE AMIP-II reanalysis (R-2), B. Am. Meteorol. Soc., 83, 1631-1643, 2002. 
Kharin, V. V., Zwiers, F. W., Zhang, X., and Hegerl, G. C.: Changes in Temperature and Precipitation Extremes in the IPCC Ensemble of Global Coupled Model Simulations, J. Climate, 20, 14191444, 2007.

Koenig, S. J., DeConto, R. M., and Pollard, D.: Late Pliocene to Pleistocene sensitivity of the Greenland Ice Sheet in response to external forcing and internal feedbacks, Clim. Dynam., 37, 1247-1268. doi:10.1007/s00382-011-1050-0, 2011.

Krantz, D. E.: A chronology of Pliocene sea-level fluctuations: The U.S. Middle Atlantic Coastal Plain record, Quaternary Sci. Rev., 10, 163-174, 1991.

Lemke, P., Ren, J., Alley, R. B., Allison, I., Carrasco, J., Flato, G., Fujii, Y., Kaser, G., Mote, P., Thomas, R. H. and Zhang, T.: Observations: Changes in Snow, Ice and Frozen Ground, in: Climate Change 2007: The Physical Science Basis, edited by: Solomon, S., Qin, D., Manning, M., Chen, Z., Marquis, M., Averyt, K. B., Tignor, M. and Miller, H. L., Cambridge University Press, 2007. Leysinger Vieli, G. J. M. C. and Gudmundsson, G. H.: On estimating length fluctuations of glaciers caused by changes in climatic forcing, J. Geophys. Res., 109, F01007, doi:10.1029/2003JF000027, 2004.

Lisiecki, L. E. and Raymo, M. E.: A Pliocene-Pleistocene stack of 57 globally distributed benthic $\delta^{18} \mathrm{O}$ records: Paleoceanography, 20, PA1003, doi:10.1029/2004PA001071, 2005.

Lunt, D. J., Foster, G. L., Haywood, A. M., and Stone, E. J.: Late Pliocene Greenland glaciation controlled by a decline in atmospheric $\mathrm{CO}_{2}$ levels, Nature, 454, 1102-1105, 2008a.

Lunt, D. J., Valdes, P. J., Haywood, A. M., and Rutt, I. C.: Closure of the Panama Seaway during the Pliocene: implications for climate and Northern Hemisphere glaciation, Clim. Dynam., 30, 1-18, doi:10.1007/s00382-007-0265-6, 2008b.

Lunt, D. J., Haywood, A. M., Foster, G. L., and Stone, E. J.: The Arctic cryosphere in the Mid-Pliocene and the future, Phil. Tran. Royal Soc. A, 367, 49-67, 2009.

Lunt, D. J., Haywood, A. M., Schmidt, G. A., Salzmann, U., Valdes, P. J., and Dowsett, H. J.: Earth system sensitivity inferred from Pliocene modelling and data, Nat. Geosci., 3, 60-64, 2010.

Lythe, M. B. and Vaughan, D. G.: BEDMAP - A new ice thickness and subglacial topographic model of Antarctica, J Geophys. Res., 106, 335-351, 2001.

Markwick, P. J.: The Palaeogeographic and Palaeoclimatic Significance of Climate Proxies for Data-Model Comparisons, The Geological Society, 251-312, 2007.

Meehl, G. A., Stocker, T. F., Collins, W. D., Friedlingstein, P., Gaye, A. T., Gregory, J. M., Kitoh, A., Knutti, R., Murphy, J. M., Noda, A., Raper, S. C. B., Watterson, I. G., Weaver, A. J., and Zhao, Z.C.: Global Climate Projections, in: Climate Change 2007: The Physical Science Basis, edited by: Solomon, S., Qin, D., Manning, M., Chen, Z., Marquis, M., Averyt, K. B., Tignor, M. and Miller, H. L., Cambridge University Press, 2007.

Naish, T. R. and Wilson, G. S.: Constraints on the amplitude of Mid-Pliocene (3.6-2.4 Ma) eustatic sea-level fluctuations from the New Zealand shallow- marine sediment record, Phil. Tran. Royal Soc. A, 367, 169-187, doi:10.1098/rsta.2008.0223, 2009.

Naish, T. R., Powell, R., Levy, R., Wilson, G., Scherer, R., Talarico, F., Krissek, L., Niessen, F., Pompilio, M., Wilson, T., Carter, L., DeConto, R., Huybers, P., McKay, R., Pollard, D., Ross, J., Winter, D., Barrett, P., Browne, G., Cody, R., Cowan, E., Crampton, J., Dunbar, G., Dunbar, N., Florindo, F., Gebhardt, C., Graham,
I., Hannah, M., Hansaraj, D., Harwood, D., Helling, D., Henrys, S., Hinnov, L., Kuhn, G., Kyle, P., Laufer, A., Maffioli, P., Magens, D., Mandernack, K., McIntosh, W., Millan, C., Morin, R., Ohneiser, C., Paulsen, T., Persico, D., Raine, I., Reed, J., Riesselman, C., Sagnotti, L., Schmitt, D., Sjunneskog, C., Strong, P., Taviani, M., Vogel, S., Wilch, T., and Williams, T.: Obliquity-paced Pliocene West Antarctic ice sheet oscillations, Nature, 458, 322 328, doi:10.1038/nature07867, 2009.

Pattyn, F., Perichon, L., Aschwanden, A., Breuer, B., de Smedt, B., Gagliardini, O., Gudmundsson, G. H., Hindmarsh, R. C. A., Hubbard, A., Johnson, J. V., Kleiner, T., Konovalov, Y., Martin, C., Payne, A. J., Pollard, D., Price, S., Rückamp, M., Saito, F., Souček, O., Sugiyama, S., and Zwinger, T.: Benchmark experiments for higher-order and full-Stokes ice sheet models (ISMIPHOM), The Cryosphere, 2, 95-108, doi:10.5194/tc-2-95-2008, 2008.

Pollard, D.: A retrospective look at coupled ice sheet-climate modelling, Climatic Change, 100, 173-194, 2010.

Pollard, D. and DeConto, R. M.: Hysteresis in Cenozoic Antarctic ice-sheet variations, Global Planet. Change, 45, 9-21, 2005.

Pollard, D. and DeConto, R. M.: A coupled ice-sheet/iceshelf/sediment model applied to a marine-margin flowline: forced and unforced variations, in: Glacial Sedimentary Processes and Products, edited by: Hambrey, M. J., Christoffersen, P., Glasser, N. F., and Hubbard, B., International Association of Sedimentologists Spec. Pub. 39, Blackwell Publ., 37-52, 2007.

Pollard, D. and DeConto, R. M.: Modelling West Antarctic ice sheet growth and collapse through the past five million years, Nature, 458, 329-332, 2009.

Pope, V. D., Gallani, M. L., Rowntree, P. R., and Stratton, R. A.: The impact of new physical parametrizations in the Hadley Centre climate model: HadAM3: Clim. Dynam., 16, 123-146, 2000.

Pritchard, H. D., Ligtenberg, S. R. M., Fricker, H. A., Vaughan, D. G., van den Broeke, M. R., and Padman, L.: Antarctic ice-sheet loss driven by basal melting of ice shelves, Nature, 484, 502-505, 2012.

Raymo, M. E., Mitrovica, J. X., O’Leary, M. J., DeConto, R. M., and Hearty, P. J.: Departures from eustasy in Pliocene sealevel records, Nat. Geosci., 4, 328-332, 2011.

Reeh, N.: Parameterization of melt rate and surface temperature on the Greenland ice sheet, Polarforschung, 59, 113-128, 1991.

Rignot, E., Velicogna, I., van den Broeke, M.R., Monaghan, A. and Lenaerts, J.: Acceleration of the contribution of the Greenland and Antarctic ice sheets to sea level rise, Geophys. Res. Lett., 38, L05503, doi:10.1029/2011GL046583, 2011.

Ritz, C., Fabre, A., and Letréguilly, A.: Sensitivity of a Greenland ice sheet model to ice flow and ablation parameters: consequences for the evolution through the last climatic cycle, Clim. Dynam., 13, 11-24, 1997.

Robinson, M. M.: New quantitative evidence of extreme warmth in the Pliocene arctic, Stratigraphy, 6, 265-275, 2009.

Robinson, M. M., Dowsett, H. J., Dwyer, G. S., and Lawrence, K. T.: Reevaluation of mid-Pliocene North Atlantic sea surface temperatures, Paleoceanography, 23, PA3213, doi:10.1029/2008PA001608, 2008.

Salzmann, U., Haywood, A. M., Lunt, D. J., Valdes, P. J., and Hill, D. J.: A new global biome reconstruction and data-model comparison for the Middle Pliocene, Global Ecol. Biogeogr., 17, 432-447, 2008. 
Serreze, M. C. and Hurst, C. M.: Representation of Mean Arctic Precipitation from NCEP-NCAR and ERA Reanalyses, J. Climate, 13, 182-201, 2000.

Sohl, L. E., Chandler, M. A., Schmunk, R. B., Mankoff, K., Jonas, J. A., Foley, K. M., and Dowsett, H. J.: PRISM3/GISS topographic reconstruction, US Geological Survey Data Series 419, 6 pp., 2009.

Solomon, S., Qin, D., Manning, M., Chen, Z., Marquis, M., Averyt, K. B., Tignor, M., and Miller, H. L. (Eds.): Climate Change 2007: The Physical Science Basis, Cambridge University Press, 2007.

Stone, E. J., Lunt, D. J., Rutt, I. C., and Hanna, E.: Investigating the sensitivity of numerical model simulations of the modern state of the Greenland ice-sheet and its future response to climate change, The Cryosphere, 4, 397-417, doi:10.5194/tc-4-397-2010, 2010.

Thompson, S. L. and Pollard, D.: Greenland and Antarctic Mass Balances for Present and Doubled Atmospheric $\mathrm{CO}_{2}$ from the GENESIS Version-2 Global Climate Model, J. Climate, 10, 871900, 1997. van den Broeke, M., Bamber, J., Ettema, J., Rignot, E., Schrama, E., van de Berg, W. J., van Meijgaard, E., Velicogna, I., and Wouters, B.: Partitioning Recent Greenland Mass Loss, Science, 326, 984 986, 2009.

Wardlaw, B. R. and Quinn, T. M.: The record of Pliocene sea-level change at Enewetak Atoll, Quaternary Sci. Rev., 10, 247-258, 1991.

Williams, T., van de Flierdt, T., Hemming, S. R., Chung, E., Roy, M., and Goldstein, S. L.: Evidence for iceberg armadas from East Antarctica in the Southern Ocean during the late Miocene and early Pliocene, Earth Planet. Sci. Lett., 290, 351-361, 2010.

Zheng, W., Braconnot, P., Guilyardi, E., Merkel, U., and Yu, Y.: ENSO at $6 \mathrm{ka}$ and $21 \mathrm{ka}$ from ocean-atmosphere coupled model simulations, Clim. Dynam., 30, 745-762, 2008. 